\title{
Adjudicating International Environmental Law Litigation: Recent Development of Case Law
}

\author{
Theodore Okonkwo \\ Department of Public Law, Faculty of Law, University of Port-Harcourt, Port-Harcourt, Nigeria \\ Email:t161962@gmail.com
}

How to cite this paper: Okonkwo, T. (2017). Adjudicating International Environmental Law Litigation: Recent Development of Case Law. Beijing Law Review, 8, 239-251.

https://doi.org/10.4236/blr.2017.83014

Received: July 13, 2017

Accepted: August 6, 2017

Published: August 9, 2017

Copyright $\odot 2017$ by author and Scientific Research Publishing Inc. This work is licensed under the Creative Commons Attribution International License (CC BY 4.0).

http://creativecommons.org/licenses/by/4.0/

\section{(c) (i) Open Access}

\begin{abstract}
This article revolves around distinct dimensions related to the international environmental legal framework. In the recent years, there have been various developments in the field of international environmental law. Some of the inter-state disputes have raised concern towards resolving environmental issues. There are three well-known cases properly discussed in this article, i.e. Indus Waters Kishenganga, South China Sea and Pulp Mills case. In all of these three cases, a new jurisdiction has been proclaimed giving a new side to the international environmental litigation. For instance, ICJ's judgement introduced the need for inclusion of EIA in the Pulp Mills case. On the contrary, the Partial Award in the case of Indus Waters Kishenganga, extended rights of India over Indus River but restricted the State from conducting extensive operations. The South China Sea case prohibited China from exercising historic rights over resources which belong to the nine dash line.
\end{abstract}

\section{Keywords}

Arbitration, Environmental, Act, Resources, Rights, Disputes, EIA, Litigation

\section{Introduction}

Environmental laws can be defined as standards which are established by governments to manage environmental quality and natural resources. The broad aspect of environment stretches from water pollution to air or even soil pollution. International law needs to be considered by all states while entering into any kind of trans-boundary operations. With growing business operations and globalisation, the environmental laws are becoming highly stringent so as to reduce extensive depletion of natural resources or regulate the adverse impact created on biodiversity. In the recent years, more number of cases has been filed in relation to environmental and procedural obligations. Each of these commer- 
cial and environmental court cases have set forth distinct standards related to the field of environmental policy. The recent explosion of population, global markets and technology has triggered establishment of international environmental law litigation. It can be argued that the state-centred policies are often not able to effectively address various international problems. In the 21 st century, the international environmental law is centred towards preventing natural resources and the environment as a whole from future exploitation. There have been recent developments in this field because the existing legal standards often fail to successfully address the global environmental concerns. This article shall highlight some jurisprudence which has added a new dimension to the existing framework of international environmental law. Some of the case laws to be discussed in this article which have initiated developments in the existing legal framework are the Pulp Mills Case, Arbitration case of South China Sea and Arbitration case of Indus Waters Kishenganga.

\section{Research Background: International Environmental Litigation}

In the past thirty two years international courts and arbitral tribunals have been upbeat in adjudicating environmental issues and interpreting the content and application of treaties and conventions in strengthening the global environmental law regime. This article deals with the issue of adjudicating international environmental law litigation and examines how the international courts and arbitral tribunals react to disputes brought before them. It examines certain case la that threw up the issues of environmental protection, resource rights and disputes associated with environmental impact assessment. The motif of this article therefore rets on two pillars: the meteoric increase in modern industrialisation and the swift response to environmental degradation by national, regional and international governments which have established adjudicating bodies to arbitrate the ever increasing cases of despoliation of the natural resources and the environment.

\section{Theory and Significance of International Environmental Litigation}

This article is intended to surmise the general principles upon which international environmental litigation is premised. It also draws on the significance of the topic which examines the rapid increase in international environmental litigation due mainly to the awareness and scientific knowledge of the injury and harm that accompany environmental despoliation the article thus, is very significant in that it is a valuable contribution to numerous others in this field on the dispute settlement mechanisms set up under the international law, particularly the 1982 United Nations Convention on the Law of the Sea (UNCLOS). UNCLOS established the International Tribunal for the Law of the sea and Annex VII arbitral tribunals. Another significance of this article, apart from being 
informative, is that it brought into focus how the minds of the various international courts works in their understanding and adjudication of environmental disputes.

Finally, it is very significant that the cases discussed in this article and other several decisions have uniquely "contributed to the development of the international environmental law by identifying and applying various rules and also by clarifying their meaning and effect and relationship with other rules of international law" which occur outside the environmental law regime.

\section{Relevance of International Environmental Litigation}

Given the above significance, this article joins the plethora of other writings in this recondite area of the law to argue on the need to rigorously strengthen the international adjudicating bodies particularly in the area of enforcement of the judgments of these international bodies. This is a worthy contribution which will definitely add to other voices urging nations of the world to take proactive steps to protect the environment within their jurisdictions and prevent activities within their domain from causing transboundary environmental harm and injuries. This article thus, constitutes a mine of information and contribution to knowledge. The point being made here is that international environmental litigation brings to the fore the role that judges, lawyers, citizens and civil society organizations need to play to ensure environmental protection through the courts. This raises the issue of public interest litigation for environmental purposes.

This article is divided into five parts-part 1 is the introduction; part 2 examines the Pulp Mills case; part 3 discusses the South China Sea Arbitration case; part 4 is on the Indus Waters Kishenganga Arbitration case; and part 5 concludes.

\section{Pulp Mills Case (ICJ Decision)}

The "pulp mill" case was basically a dispute which took place between Uruguay and Argentina. It can be stated that dispute took place regarding pulp mills' construction over Uruguay River. During that time, the presidents were Tabaré Vázquez of Uruguay and Néstor Kirchner of Argentina ${ }^{1}$. Both parties had entered into major public relations, diplomatic and economic conflict. On the contrary, the dispute had also affected transportation and tourism business operations which were prevalent between the regions (Sebastian \& Olav, 2011). The International Court of Justice (ICJ) was held accountable for carrying forward the legal proceedings (Timothy, 2014). The ICJ concluded by claiming that Uruguay's failing in informing Argentina about the operations was highly inappropriate, but the operations certainly did not lead to river pollution (Alexander, 2014). Therefore, the allegation of pulp mill being closed due to river pollution was definitely not justified. In 2010, the dispute had finally ended by announcing ${ }^{1}$ [2010] ICJ Rep, General List No. 135. 
joint coordination of various activities to be exhibited on the river. The ICJ's legal declaration was a highly recognised one in context of environmental disputes, simply because Environmental Impact Assessment (EIA) had gained a customary value (Timothy, 2014). The case highlighted the need for EIA whenever there are transboundary effects inter-linked with pollution risks (Ulrich \& Thilo, 2011). 1975 Statute was applied while making the judgement, so as to understand whether procedural obligations have been really breached by Uruguay and its compliance with distinct environmental standards ${ }^{2}$.

The principal claims which were made by Argentina included that Uruguay was not strictly aligned with the consultation and notification procedure as mentioned within the Statute (Sebastian \& Olav, 2011). It was even stated that construction of pulp mills were without taking any prior consent from Argentina. Another claim made was the constructed mills would have polluted the river and even surrounding areas (Ved \& George, 2012). To be more specific, the two mills would have breached obligation of Uruguay in context of the Statute focused on preserving the aquatic environment (Alexander \& Robert, 2012). The argument placed was that the mills' operations would disrupt fisheries and biodiversity (Jonathan, 2013). Both environmental and procedural obligations were taken into account by the ICJ while making the final judgement (Oran, 2011). The ICJ noted that procedural obligations were breached by Uruguay through keeping CARU uninformed about the construction of the mills, prior to issuing environmental authorisations (Steven \& Benjamin, 2012). Arguably, Argentina had been notified but the entire communication was not through CARU and the procedure was exhibited by the Uruguayan government only after issuing authorisations (Bruno, 2013). Articles 7 to 12 embedded within the Statute was not strictly followed because co-operation mechanisms were not effectively addressed (Steven \& Benjamin, 2012). Argentina claimed that four distinct environmental obligations were breached by Uruguay. The obligations can be classified as-to contribute towards rational and optimum utilisation of river water, to ensure the woodland and soil management did not contradict waters' quality, to preserve marine life and restrict pollution, and collaborating measures for avoiding changes within the ecological balance (Martin, Robert, \& Sarah, 2011). In this case, a new dimension was added on to the international environmental litigation (Ulrich \& Thilo, 2011). It can be argued that both the claims were not strictly considered by the ICJ. In relation to environmental obligations, the ICJ put across the fact that Argentina did not mention the discharge limits proclaimed in the Statute being exceeded by Botnia mill's operations (Jonathan, 2013). The ICJ not only considered the Statute's wordings but also reflected upon the domestic regulations which are associated with the Statute (Richard, 2012). During the judgement, it was mentioned by the ICJ that EIA is an essential entity when it comes to assessing impact of trans-boundary operations (Ved \& George, 2012). The ICJ also put across the claim that it has become necessary ${ }^{2}$ [2010] ICJ Rep, General List No. 135. 
to integrate EIA within the general international law (Michael et al., 2013). In this case, the facts were presented in a manner that it would appear inauguration of mills has resulted into extensive river pollution (Richard, 2012). The importance of EIA arises when it is not possible to evaluate the actual environmental impact caused by certain operations (Ruchi, 2017). There was no such evidence presented in Argentina v. Uruguay case to highlight that the later had not acted with due diligence or the mill's discharged effluents have disrupted ecological balance or water quality since incorporation of operations in 2007 (Ole, David, \& Wang, 2011).

The implications of the case law can be best evaluated in terms of the jurisprudence which had been created (Martin, Robert, \& Sarah, 2011). It can be stated that while exploring environmental legal principles, it becomes necessary to investigate human rights encompassed within legal disputes (Ruchi, 2017). EIA is that tool which helps in respecting human rights' elements strongly linked with environmental standards (Ole, David, \& Wang, 2011). There are still loopholes prevalent within the international environmental law and inclusion of EIA has helped in addressing some of the loopholes (Oran, 2011). The ICJ judgment had shifted focus of individuals towards a new jurisprudence where EIA does not form an important component of the customary international law; however, it shall address obligations related to due diligence (Michael et al., 2013). An area has been left unanswered in the pulp mill case, i.e. whether relevance of EIA would exist or will emerge only when there is any human rights' obligation (Barry \& Barry, 2012)? The jurisprudence of including EIA within the international environmental law shall gain further significance with future developments in this particular area (Alexander \& Robert, 2012). It is evident from this case that the ICJ's judgement revolved around proving that the Uruguay's wrongful conduct was a mere reflection of Argentina's satisfaction. In transboundary operations, disputes often emerge due to environmental standards (Bruno, 2013). Therefore, in scenario where cross-boundary operations are involved, the need for impact assessments arises (Philippe, 2017). In the future scenario, the international tribunals and the national courts would surely take into account the ICJ's jurisprudence in the pulp mill case. The ICJ's final judgement was given while critically examining Article 41(a) included within the 1975 Statute (Philippe, 2017). When a state guarantees operations being conducted with due diligence, then it becomes essential to conduct a thorough environmental assessment (Alan, 2012). On the contrary, when trans-boundary operations constitute the risk of industrial activities having an adverse impact on the environment then the inclusion of EIA becomes mandatory (Dirk, Andreas, \& Sandra, 2011). Customary law obligations should not only be confined to investigating the basic environmental standards (Manfred, et al., 2012). From a broader perspective, states must even conduct EIA so as to address their due diligence obligation (Jessica \& Enrique, 2012).

There are different case laws which fall under the international environmental 
litigation. The jurisprudence of each of these cases has demonstrated a specific area of interest (Barry \& Barry, 2012). For instance, in the pulp mill case focus was on integration of EIA. The case considered various Articles embedded within the legal statute (Alan, 2012). However, inclusion of EIA was definitely a new dimension in the overall legal scenario (Vandana, 2016). Rapanos v. United States can be considered as another example where some unique jurisprudence had resulted in context of management of water bodies (Jessica \& Enrique, 2012). The case was focused on analysing the outreach of the Clean Water Act (Dirk, Andreas, \& Sandrak, 2011). It was one of the recognised environmental cases which challenged federal jurisdiction in terms of regulating isolated wetlands (Frank, 2017). The court's proceedings outlined that wetlands which does not consist of ecological or hydrological link to navigable waters cannot be considered to fall under the jurisdiction associated with the Clean Water Act (Frank, 2017). Hence, this case law revealed that there are some loopholes present within the standardised legal jurisdiction ${ }^{3}$. Therefore, applying the Clean Water Act to a particular case scenario would also require considering other facts and figures ${ }^{4}$. The international environmental law still needs a lot of restructuring (Vandana, 2016). There is exclusive jurisprudence which has emerged in context of a specific case. It is always not restricted to studying origin of a particular case (Vandana, 2016). Arguably, the additional legal norms and human rights' obligations also should be taken into account while scrutinising international environmental law. The extent of adverse impact being caused needs to be firstly assessed so as to formulate best possible legal decisions.

\section{South China Sea Arbitration Case (PCA)}

The South China Sea Arbitration case is one of the landmark cases under environmental law litigation (David et al., 2011). The case was brought by Republic of the Philippines against the People's Republic of China based on the United Nations Convention on the Law of the Sea (David et al., 2011). The nature of the clash lacked clarity, since overlapping claims were made by both the parties on the basis of geographical proximity, history and principles of the marine time law. China's over confidence has made the situation worse (Susan, 2013). Furthermore, it has raised the security concerns in the region. China claimed that the South China Sea is based on their historic rights that are approved by the imperial maps of the Ming dynasty (Karen, 2011). During the last two decades, China's economic activities, legislative proposals and maritime law enforcement attempts approved its maritime and territorial claims regarding the South China Sea (Panos, 2015). Therefore, the Law of People's Republic of China on the Exclusive Economic Zone and Continental Shelf declared that the historic rights enjoyed by China should not be affected by the provisions in this Law. The conflict between them has led to the international arbitration between China and Philippines. China claimed that the nine dotted lines are invalid as it violated the 
Maritime Law established by the United Nations Convention on the Law of the Sea (UNCLOS). On the other hand, Philippines claimed that the allegations imposed by China were totally irrelevant as China disobeyed the agreement on the ground of exclusive economic zone.

The Permanent Court of Arbitration (PCA) was solely responsible to handle the legal dispute. The decision was in favour of Philippines (Richard, 2014). The verdict of the case did not change the behaviour of China (David, 2012). They have claimed the verdict as null and void (Virginie, 2012). The mentality of China was highlighted through this case as they neither accepted the verdict nor have they rejected it. China's claim was proved to be irrelevant and The Hague ruled out the claim (Panos, 2015). Beijing had no entitlement regarding South China Sea to an economic zone within 200 miles of Thomas reefs and Mischief (Matthew, 2013). Five powerful conclusions that can be summarised from Permanent Court of Arbitration's 500 page verdict are as follows-firstly, the claim by Beijing was not at all sensible stating that they have rights to exercise within the nine-dash-line located exactly in South China Sea, secondly, Philippines was granted right to exploitation of natural resources, since the maritime region around the Second Thomas Shoal and Mischief Reef were within the Exclusive Economic Zone (Virginie, 2012).

Thirdly, China's conduct and building activities in the Mischief Reef constitutes the breaking of the legal obligations under the UNCLOS (David, 2012). The main reason was the preservation of the marine ecosystem and settlement of the maritime disputes peacefully (Farhana, 2012). Fourthly, China had a positive obligation not to block the Filipino fishing vessels for exercising their exclusive rights. Hence, to prevent the Chinese fisherman from taking advantage of the same resources. Lastly, China would not harden its unlimited claim to their territory which is under an area of doubt, as the PCA has not made any announcement over the validity of the nine-dash-line. Recently, Philippines are trying to improve their relations with China (Karen, 2011).

One of the strategic implications needs to be the tribunal award that could not deal with the major issue at risk regarding South China Sea. It was claimed wrongfully to the protective dominion over the Spartly Islands. It was due to the reason that tribunal is constituted under the UNCLOS. Hence, it can only be capable of considering the questions that are related to the understanding of the convention. For instance, the states under maritime zones can impose claim through referring to the above statement. The treaty particularly deletes the territorial disputes. Article 121 was interpreted by the tribunal which elaborates on the establishment of the islands. The tribunal additionally offered tests for determining the materials that the island was composed of. It mattered greatly as the meeting islands were labelled as 200 nautical miles Exclusive Economic Zone. However, a simple rock was entitled with the 12 nautical miles in the territorial sea (Susan, 2013). The law court stated that its test confirmed that no island exits in Spratlys, therefore, neither any of the claimant state nor China itself can claim 200 nautical miles Exclusive Economic Zone. Most importantly the 
tribunal reduced the scope to a great extent of maritime entitlements that states can claim regarding the South China Sea (Farhana, 2012). The committee finalized with a restriction to China that they cannot claim to have historic rights to resources within the nine dash line that appears in the Chinese maps in the United Nations Convention on the Law of the Sea.

One of the most prominent cases with regards to the international environmental law litigation is Nicaragua v. Colombia (Oliver, 2011). It was the territorial disputes that have been highlighted in this case similar to South China Sea arbitration case (James, 2013). The territorial dispute included with Columbia over the Quita Sueno Bank and Archipelago de San Andres y Providencia (Oliver, 2011). Additionally, they have maritime conflicts with Honduras in the Caribbean Sea and a boundary with Costa Rica over Rio San Juan (Matthew, 2013). The case was brought by Nicaragua in the year 2001. It was found that there were no much Maritime issue as in 1928 the only cause would have been a conflict over the overlapping claims to 3 nautical miles territorial sea (Duncan \& Rajamani, 2013). However, the islands were very far from each other over 100 nautical miles, therefore, it cannot be regarded as an issue ${ }^{5}$. Initially, there is no such law of the sea that can prevent the Columbian Navy to operate throughout this region (Duncan \& Rajamani, 2013). The outer line limit of Nicaraguan territorial sea is most probably 12 nautical miles from the Nicaraguan Coast ${ }^{6}$. The maritime law enforcement actions are not at all affected by the obligations and rights contained under UNCLOS. The ICJ judgment did not affect the Columbian Navy much. Additionally, the dispute is now settled by mutual cooperation. Both Nicaragua and Columbia have an interest in putting an end to this above-prescribed traffic through their waters (James, 2012). US had supported them both in this dispute. In the long run, the judgment will serve as improving the conditions and reducing their activities affecting the sea.

\section{Indus Waters Kishenganga Arbitration Case}

On February 2013, a partial award was offered in the case of Indus Waters Kishenganga arbitral dispute between India and Pakistan. The inter-state dispute mainly revolved around India's proposal for building a hydroelectric project of 330 megawatt on Kishenganga River which forms a tributary of the widely known Jhelum River. The disputed area was a part of Jammu and Kashmir and administered by India. It can be stated that the main point of conflict was the Neelum River which emerged from the Kishenganga was under Pakistan-administered Kashmir (Sian, 2013). The Jhelum River's hydroelectric potential is not hidden from Pakistan and the government had even undertaken decision of constructing Neelum-Jhelum hydroelectric project (NJHEP) of 969 megawatt. Kishenganga Hydro-Electric Project (KHEP) had raised concern towards irrigation problem or shortage of water supply. Pakistan had filed a legal suit because of KHEP's impact on the water supply. In May 2010, the arbitration was filed 
under Indus Waters Treaty (IWT).

The partial award allowed India to continue the construction of KHEP (Peter, 2015). The Final award will determine the downstream minimum flow of water (Jane, 2012). Additionally, it has prevented India from using flushing for the sediment control at the KHEP (Jane, 2012). Furthermore, the prohibition is also on running the future plant in rivers belonging to the western part. It is the first time arbitration instrument provided in the treaty has been used. The previous conflicts between the parties were resolved either by the appointment of a neutral expert or through negotiations. Initially, Pakistan had requested the court to figure out whether this change in course breached India's accountability under this Treaty (Peter, 2015).

The legal scenario can be properly understood through exploring the concept of Indus Waters Treaty. The IWT of 1960 can be denoted as negotiations set out by the World Bank for regulating the obligations and rights of both the Parties, i.e. Pakistan and India for exploring water resources of the Indus River. There are some exceptions mentioned in the Treaty, but, initially Western rivers had been assigned to Pakistan, whereas, Eastern Rivers' unrestricted usage was offered to India. Arguably, the Treaty does not take into account the disputed areas of Jammu and Kashmir where the river has its tributaries (Simon, 2012). The Permanent Indus Commission is solely responsible for resolving disputes which fall under the IWT (Sian, 2013). However, if some matter still cannot be resolved by the Commission then it results into a major difference (Zygmunt et al., 2016). The highlighted dispute was initiated because the Treaty did not emphasise upon the controversial areas between India and Pakistan (Richard et al., 2011). There were still vague areas regarding rights of both the Parties on conducting operations over the Indus River.

Probably, this case can be regarded as the first dispute which was forwarded to the Arbitration Court. Pakistan had focused on two important questions, that is, whether inter-tributary transfer of India had breached obligations associated with the IWT and whether the agreement enabled India to deplete the reservoir content beyond the level of "dead storage" (Elena et al., 2015). Hence, this case of arbitration constituted two major disputes. At the end of dispute resolution, a partial award was framed in 2013 to enable India to proceed with operations and construction of KHEP (Richard et al., 2011). In the Final Award, there were some operational constraints which were clearly specified (Simon, 2012). The Parties agreed upon the fact that such awards need to be published, however, later, Pakistan opposed pleadings' publication (Ole, 2012).

The international environmental law litigation encompasses various legal regulations revolving around distribution and management of inter-state rivers (Donald \& Tim, 2016). For instance, the River Boards Act was established in 1956 (Lakshman \& Mariah, 2017). As per this Act, the board was assigned certain responsibilities, such as ensuring optimum and proper resource utilisation in context of inter-state rivers and effectively monitoring varying schemes of 
hydroelectricity power generation, water supply and irrigation facilities (Donald \& Tim, 2016). On the other hand, the National Water Policy (1987) mainly dealt with water distribution among states (Alexander, 2014). According to this policy, a participatory approach is the preliminary requisite for management and development of water resources in an integrated and holistic manner (Lakshman \& Mariah, 2017). Arguably, the signing of the Partial Award was certainly a new jurisdiction in the history of international environment law (Zygmunt et al., 2016). For both the Parties, this Award was a basic attempt towards striking a balance between competing rights possessed by the States (Ole, 2012). The Partial Award enables India to exhibit all construction activities related with the KHEP. On the contrary, the Award even restricts India from utilising drawdown flushing in order to control sediment level in context of KHEP case. Similar litigation is expected to be applicable in case of any such river plant located on Western Rivers (Elena et al., 2015).

The Jhelum is considered as a very important river inside the overburdened Indus river system which flushes large areas of the Pakistan and India (Shawkat, 2012). Pakistan was quite concerned by the impact of the KHEP on its supply of water (Shawkat et al., 2012). It resulted in filing a request for arbitration on May 2010. It has been witnessed that the partial award which has been awarded resulted in the construction of other plants (Joshua \& Stefano, 2012). The successful resolution of this dispute may result into the restoring of international arbitration procedure. In the international context, this treaty will help other countries not to disrupt the flow of water; it will be the duty of one country to ensure that minimum level of water flows into another country (Joshua \& Stefano, 2012).

\section{Conclusion}

This article has highlighted important cases under the International Environmental Law Litigation (James, 2012). The first case was the Pulp Mill dispute between Uruguay and Argentina. It took place in the year 2010 and it was mainly an environmental dispute between the above-mentioned nations (James, 2012). The dispute mainly took place from the authorisation of the CMB pulp mill by Uruguay to the actual construction of the Botania pulp mill which was situated on the banks of the river Uruguay (Lung-chu, 2014). It constituted an international boundary between Uruguay and Argentina (Lung-chu, 2014). The court came to the judgment that Uruguay has violated the procedural obligations without informing Argentina for the construction of pulp mills (Arend \& Beck, 2014). The court gave an important judgment regarding this case, that it is an absolute necessity to investigate the human rights encircled within the legal disputes. The second case was South China Sea arbitration case. The dispute was between China and Philippines under the United Nations Convention on the Law of the Sea (Arend \& Beck, 2014). The arbitration was mainly concerned with the historic rights and maritime entitlements relating to the South China 
Sea. The Permanent Court of Arbitration offered as Registry in this arbitration. Above mentioned cases highlighted the common fact regarding the violation of environmental rules and laws (Michael, 2013). The environment is regarded as the most important component of Mother Earth, so several laws have been initiated to protect it (Alina, 2015). Such laws include Maritime Law, Law of Sea, Clean Water Act, etc. The environmental law applies to the governments or even the private parties (Michael, 2013). The environmental law helps to manage the environmental quality and natural resources that are subjected to threat (Alina, 2015). In conclusion, international environmental litigation will continue to drive the regime of international environmental law.

Notwithstanding the fact that this article was painstakingly written, some limitations and shortcomings still abound. First is the dearth of materials which are not easy to find in this part of the world. Second, browsing and sourcing for materials on the internet most times is very frustrating due to poor internet services. Finally, there is the limitation of reconciling the different approaches which the courts and the tribunals adopted in reaching their decisions in environmental disputes initiated before them. These limitations therefore, suggest the need for further research as there are still many unanswered questions in the decisions of the international tribunals discussed in this article.

\section{References}

Alan, B. (2012). Human Rights and the Environment: Where Next? EJIL, 23, 628.

Alexander, G. (2014). International Environmental Law, Policy, and Ethics (pp. 130-144). Oxford: OUP.

Alexander, O., \& Robert, O. K. (2012). Institutional Diffusion in International Environmental Affairs. $I A, 88,530$.

Alina, K.-I. (2015). Public International Law. Routledge, 922, 21-67.

Arend, C. A., \& Beck, R.J. (2014). International Law and the Use of Force: Beyond the UN Charter Paradigm. Routledge, 288, 27-174.

Barry, S., \& Barry, D. D.-C. (2012). Strategic Environmental Assessment: A Sourcebook and Reference Guide to International Experience. Earthscan, 26-29.

Bruno, D. (Ed.) (2013). Environmental Policy in Search of New Instruments (pp. 143144). Springer Science \& Business Media.

David, A. (2012). International Law and International Relations (pp. 125-298). Theo Farrell and Hélène Lambert: Cambridge University Press.

David, R. C., Christopher, L. B., \& Daniel, M. S. (2011). Environmental Law Handbook. Government Institutes, $961 \mathrm{p}$.

Dirk, U. G., Andreas, R., \& Sandra, W. (2011). Accountability in a Global Economy: The Emergence of International Accountability Standards. BEQ, 21, 28.

Donald, R. R., \& Tim, S. (2016). The International Law of the Sea (pp. 1-528). London: Bloomsbury Publishing.

Duncan, F., \& Rajamani, L. (2013). Climate Change and International Environmental Law: Musings on a Journey to Somewhere. Journal of Environmental Law, 25, 437-461. https://doi.org/10.1093/jel/eqt022

Elena, M. B. et al. (2015). Linking Biodiversity, Ecosystem Services, and Human Well- 
Being: Three Challenges for Designing Research for Sustainability. Current Opinion in Environmental Sustainability, 14, 76-85. https://doi.org/10.1016/j.cosust.2015.03.007

Farhana, Y. (2012). Climate Change and Carbon Markets: A Handbook of Emissions Reduction Mechanisms (pp. 289-321). Abingdon: Routledge.

Frank, B. (2017). A World Environment Organisation: Solution or Threat for Effective International Environmental Governance (pp. 1-296)? Abingdon: Routledge.

James, C. (2012). Brownlie's Principles of Public International Law. Oxford: Oxford University Press.

James, H. (2013). Reflections on the Role of International Courts and Tribunals in the Settlement of Environmental Disputes and the Development of International Environmental Law. Journal of Environmental Law, 25, 501-514. https://doi.org/10.1093/jel/eqt018

Jane, M. A. (2012). Climate Change, Forced Migration, and International Law (pp. 119266). Oxford: Oxford University Press.

Jessica, C., \& Enrique, C. (2012). Ecotourism and the Development of Indigenous Communities: The Good, the Bad, and the Ugly. Ecological Economics, 73, 47-55. https://doi.org/10.1016/j.ecolecon.2011.10.024

Jonathan, G. (2013). Global Competition and EU Environmental Policy (pp. 1-30). Abingdon: Routledge.

Joshua, B., \& Stefano, P. (2012). Selling Forest Environmental Services: Market-Based Mechanisms for Conservation and Development (pp. 235-260). Abingdon: Taylor \& Francis.

Karen, N. S. (2011). International Environmental Governance: Managing Fragmentation through Institutional Connection. Melbourne Journal of International Law, 12, 2-40.

Lakshman, G., \& Mariah, L. (2017). International Environmental Law in a Nutshell (pp. 1-842). St Paul, MN: West Academic.

Lung-chu, C. (2014). An Introduction to Contemporary International Law: A PolicyOriented Perspective (pp. 1-641). Oxford: Oxford University Press.

Manfred, L. et al. (2012). International Trade Drives Biodiversity Threats in Developing Nations. Nature, 486, 109-112. https://doi.org/10.1038/nature11145

Martin, D., Robert, M., \& Sarah, W. (2011). Cases and Materials on International Law (pp. 1-832). Oxford: Oxford University Press.

Matthew, H. (2013). Victims of Environmental Harms and Their Role in National and International Justice. Emerging Issues in Green Criminology. London: Palgrave Macmillan.

Michael, B. (2013). International Law and the Arctic (pp. 1-320). Cambridge: Cambridge University Press.

Michael, S. et al. (2013). Strategic Environmental Assessment and Land Use Planning: An International Evaluation. Abingdon: Routledge.

Ole, K. F., David, H., \& Wang, X. (2011). Yearbook of International Environmental Law 2009. In O. Kristian (Ed.), Yearbook of International Environmental Law (pp. 217-480, 707-746). Oxford: Oxford University Press.

Ole, W. P. (2012). An International Environmental Court and International Legalism. Journal of Environmental Law, 24, 547-558. https://doi.org/10.1093/jel/eqs022

Oliver, A. H. (2011). Taking Back Eden: Eight Environmental Cases That Changed the World (pp. 1-256). Washington DC: Island Press.

Oran, R. Y. (2011). Effectiveness of International Environmental Regimes: Existing Know- 
ledge, Cutting-Edge Themes, and Research Strategies. Proceedings of the National Academy of Sciences of the United States of America, 108, 19858.

Panos, K. (2015). EU International Relations Law (pp. 1-644). London: Bloomsbury Publishing.

Peter, M. H. (2015). Epistemic Communities, Constructivism, and International Environmental Politics (pp. 119-233). Abingdon: Routledge.

Philippe, C. (2017). Differential Treatment in International Environmental Law (pp. 1224). Abingdon: Routledge.

Richard, B. M. (2014). Regulation, Enforcement and Governance in Environmental Law (pp. 1-776). London: Bloomsbury Publishing.

Richard, K. M. (2012). Environmental Impact Assessment: The State of the Art. Impact Assessment \& Project Appraisal, 30, 5-14. https://doi.org/10.1080/14615517.2012.661557

Richard, S. et al. (2011). International Business Law and Its Environment. Boston, MA: Cengage Learning.

Ruchi, A. (2017). International Environmental Justice: A North-South Dimension (p. 1). Abingdon: Routledge.

Sebastian, O., \& Olav, S. S. (2011). Managing Institutional Complexity: Regime Interplay and Global Environmental Change (pp. 1-376). Cambridge, MA: MIT Press.

Shawkat, A. et al. (2012). Handbook of International Environmental Law. Abingdon: Routledge.

Sian, S. (2013). Banking Nature? The Spectacular Financialisation of Environmental Conservation. Antipode, 45, 198-217. https://doi.org/10.1111/j.1467-8330.2012.00989.x

Simon, M. (2012). Strategic Environmental Assessment in International and European Law: A Practitioner's Guide (pp. 1-347). Abingdon: Earthscan.

Steven, B., \& Benjamin, C. (2012). Complex Global Governance and Domestic Policies: Four Pathways of Influence. International Affairs, 88, 585-604. https://doi.org/10.1111/j.1468-2346.2012.01090.x

Susan, J. B. (2013). Understanding Environmental Administration and Law (pp. 229232). Washington DC: Island Press.

Timothy, O. R. (2014). Environmental Science for Environmental Management (pp. 1-538). Abingdon: Routledge.

Ulrich, B., \& Thilo, M. (2011). International Environmental Law (pp. 1-452). London: Bloomsbury Publishing.

Vandana, S. (2016). Earth Democracy: Justice, Sustainability and Peace (pp. 1-240). London: Zed Books.

Ved, N., \& George, R. P. (2012). International Environmental Law and Policy for the 21st Century (pp. 1-668). Boston, MA: Martinus Nijhoff Publishers.

Virginie, B. (2012). Sustainable Development in International Law: Nature and Operation of an Evolutive Legal Norm. European Journal of International Law, 23, 376.

Zygmunt, P. J. B. et al. (2016). Environmental Law and Policy: Nature, Law, and Society. Alphen aan den Rijn: Wolters Kluwer Law \& Business. 
Submit or recommend next manuscript to SCIRP and we will provide best service for you:

Accepting pre-submission inquiries through Email, Facebook, LinkedIn, Twitter, etc. A wide selection of journals (inclusive of 9 subjects, more than 200 journals)

Providing 24-hour high-quality service

User-friendly online submission system

Fair and swift peer-review system

Efficient typesetting and proofreading procedure

Display of the result of downloads and visits, as well as the number of cited articles Maximum dissemination of your research work

Submit your manuscript at: http://papersubmission.scirp.org/

Or contact blr@scirp.org 